\title{
Crise e desregulação do trabalho no Brasil
}

\author{
JOSÉ CELSO CARDOSO JR.
}

\begin{abstract}
RESUMO : Este texto discute, numa perspectiva histórico-estrutural, a trajetória recente (1980-2000) de transformações da economia brasileira, especialmente no que diz respeito às implicações sobre o seu mercado de trabalho. Sucintamente, há 3 aspectos de interesse no texto. O primeiro está relacionado à tarefa de estabelecer as conexões lógico-históricas entre a crise da economia brasileira dos últimos vinte anos (1980-2000) e o processo de desregulação do trabalho no país. O segundo trata de definir e caracterizar cada um dos dois eixos que, do nosso ponto de vista, compõem o quadro de desregulação do trabalho no Brasil em período recente, a saber: a desestruturação e a desregulamentação do mercado de trabalho. Por fim, o terceiro aspecto abordado no texto procura avançar na sugestão de alguns pontos de reflexão para a tentativa de se construir uma agenda positiva de mudanças, como condição para a superação do binômio crise econômica e desregulação do trabalho no Brasil.
\end{abstract}

\section{Introdução: demarcação histórica e conceitual do problema}

crise recente da economia brasileira tem suas raízes históricas fincadas na segunda metade da década de 1970. Do ponto de vista interpretativo, ela é fruto do desmonte do projeto nacional-desenvolvimentista fundado, grosso modo, nos anos 30, aprofundado na década de 1950 e rompido nos anos 80 . Durante este período, a economia brasileira havia conseguido - bem ou mal não importa muito aqui - transitar
PATAVRA,S - CHAVE: crise econômica, desregulação, desestruturação, desregulamentação, mercado de trabalho, Brasil.

Doutorando do IEUnicamp e Pesquisador do IPEA 
rapidamente de uma estrutura agrário-exportadora para uma sociedade industrial, ampla e caoticamente urbanizada.

Com a crise econômica que tomou conta do país no bojo da implementação do II PND nos anos 70, instalou-se, a um só tempo, o colapso do modelo político desenvolvimentista e a reversão das tendências de crescimento de sua economia. Assim, enquanto a década de 1980 foi representante da primeira fase da regressão industrial do país, os anos 90 podem ser vistos como palco da segunda fase da trajetória brasileira de regressão industrial. Nesses 20 anos de desorganização do parque produtivo doméstico, os anos 80 representaram, portanto, o momento de desarticulação do desenvolvimento industrial interno, enquanto os anos 90 simbolizariam o colapso daquela estratégia pretérita de crescimento industrializante, com conseqüências adversas para o futuro do país (cf. Cardoso Jr. \& Pochmann, 2000).

A primeira fase, transcorrida ao longo da década de 1980, desenrolou-se num ambiente de intensa instabilidade macroeconômica, em que baixas taxas de crescimento do produto interno e altas taxas de inflação espelhavam, de um lado, a ruptura das fontes e fluxos de financiamento externos e, de outro, o esforço exportador visando a obtenção de expressivos saldos comerciais. A concepção a respeito dos descaminhos da economia brasileira neste período procura enfatizar a idéia de que muito contribuiu, para o aprofundamento da crise, o padrão de ajustamento macroeconômico efetuado no período 1979/83 (cf. Baer, 1993).

Após o período relativo ao ajustamento externo, no início da década, a economia produziria grandes e seguidos superávites em suas contas externas, associados ao baixo nível de absorção interna e às recorrentes desvalorizações cambiais. Entretanto, os superávites gerados tinham como principal finalidade a transferência de recursos reais ao exterior, devidos em sua maior parte ao pagamento de juros sobre a dívida externa contraída em períodos anteriores. Pelo fato de a dívida externa brasileira encontrar-se, desde os primeiros anos da década de 1980, praticamente toda em mãos do Estado, e considerando ainda que os setores privados eram em grande parte os detentores dos saldos comerciais conquistados nestes anos, o setor público precisava adquirir as divisas em moeda estrangeira para enviá-las ao exterior, valendo-se, para tanto, de emissão de dívida pública interna, principal responsável pelo endividamento crescente do setor público ao longo da década (cf. Cruz, 1984; Carneiro, 1992).

O caráter financeiro do déficit público fez com que taxas de juros crescentes e prazos cada vez mais curtos se tornassem a regra, comprometendo seriamente a capacidade de financiamento do Estado brasileiro diante da crise. É no bojo deste quadro de desajustamento patrimonial do setor público que a inflação viria a se constituir no principal problema macroeconômico da década de 1980, suscitando o deslocamento do eixo das discussões, que antes girava em torno da problemática do desenvolvi- 
mento econômico com endividamento externo crescente, para centrar-se em torno das causas e conseqüências da inflação em países de industrialização retardatária ou em contextos de subdesenvolvimento crônico. Na prática, o binômio ajuste externo - desajuste interno estabeleceu as condições para a perpetuação da crise e da inflação, e materializou, em grandes proporções, um tipo de apartheid social único em economias com o grau de urbanização e industrialização similares ao do Brasil.

Como conseqüência da alternativa seguida, gerou-se um setor público altamente endividado e imobilizado, ao mesmo tempo que um setor privado financeiramente saneado. Com isso, na medida em que se elegeu o setor público como depositário dos custos do ajustamento externo da economia, criou-se uma situação na qual o Estado foi perdendo o poder de outrora de condutor do desenvolvimento, seguindo o país o rumo da estagnação. O capital privado, movendo-se por estímulos de mercado, notadamente rentáveis no curto prazo, transferiu e concentrou grande parte de sua riqueza em ativos financeiros ao invés de produtivos. Ainda mais, não foi capaz de ocupar o espaço do setor estatal com o objetivo de redirecionar o sentido do desenvolvimento, fundando um novo pacto político apto a dar conta da superação da crise (cf. Tavares \& Fiori, 1993; Fiori, 1995).

Nesta etapa inicial de desarticulação do modelo de desenvolvimento industrial, houve também a ruptura do padrão de estruturação do mercado de trabalho, que se refletiu em basicamente 5 fenômenos interligados. Primeiro, no perfil setorial das ocupações urbanas localizadas no terciário (comércio e serviços). Segundo, no alargamento dos segmentos considerados pouco estruturados do mercado de trabalho (trabalhadores sem carteira assinada, pequenos empregadores, trabalhadores por conta própria e trabalhadores não remunerados). Terceiro, na tendência à precarização ou perda de qualidade dos postos de trabalho (desassalariamento formal, perda de direitos sociais, trabalhistas e previdenciários, jornadas de trabalho mais longas, remuneração oscilante no tempo, múltiplas fontes de rendimentos, etc.). Quarto, na estagnação das remunerações provenientes do trabalho, em particular dos segmentos assalariados da estrutura ocupacional. Quinto, na piora distributiva funcional (repartição da renda entre rendimentos do capital e do trabalho) e pessoal (repartição dos rendimentos do trabalho entre os ocupados). Um sexto elemento desestruturador do mercado de trabalho - o aumento dos níveis de desocupação e desemprego aberto - viria se manifestar com maior intensidade somente nos anos 90, incorporando-se a partir daí no conjunto de fatores a caracterizar empiricamente o fenômeno da desestruturação do mercado de trabalho brasileiro (cf. Medeiros \& Salm, 1994; Mattoso \& Pochmann, 1998).

Em suma, tem início no Brasil dos anos 80, por decorrência mais geral da crise econômica, a trajetória de desregulação do mercado laboral que, nesta primeira etapa, é marcada ainda por um movimento 
contraditório: de um lado, ocorre uma desregulação impulsionada pela tendência de desestruturação do mercado de trabalho; de outro, ocorre uma tentativa de regulação motivada pela regulamentação deste mesmo mercado. Em outras palavras, a regulação capitalista clássica do mercado de trabalho passa, no Brasil, por uma fase de amadurecimento, que se dá basicamente entre as décadas de 1930 e 1980, a partir de quando tem início uma fase de reversão imperfeita (ou ainda inconclusa), dentro da qual se situam atualmente os marcos da (des)regulação do trabalho no país. Para que não pairem dúvidas ou confusões semânticas acerca do objeto sob investigação nesta pesquisa, é conveniente precisar melhor cada um destes conceitos: (des)regulação, (des)estruturação e (des)regulamentação do mercado de trabalho.

A regulação do trabalho é aqui entendida como a síntese de 2 vetores de determinação. De um lado, o vetor da estruturação do mercado laboral em consonância à emergência, consolidação e avanço das relações capitalistas de produção no país, as quais dizem respeito, basicamente, à difusão do assalariamento da mão-de-obra pelo sistema econômico e sua concomitante aceitação pela sociedade. De outro lado, o vetor da progressiva regulamentação deste mesmo mercado de trabalho, que se dá a partir de uma interferência pública (estatal e civil) mediadora e disciplinadora das relações e condições de trabalho.

O vetor da estruturação do mercado laboral é fundamentalmente dependente do padrão de desenvolvimento que se instala na sociedade, ou mais especificamente, da natureza do capitalismo que constitui (e põe em operação) determinadas bases produtivas de valorização do capital. Por sua vez, o vetor da progressiva regulamentação do mercado de trabalho depende do grau de organização política e social da nação e se apresenta como um conjunto de instituições públicas (estatais e civis) e normas legais que visam fornecer os parâmetros mínimos de demarcação e funcionamento do mercado de trabalho, notadamente no que diz respeito ao uso do trabalho (regulamentação das condições de contratação, demissão e da jornada de trabalho), sua remuneração (regulamentação das políticas e reajustes salariais em geral e do salário mínimo) e proteção ou assistência social aos ocupados e desempregados (regulamentação dos direitos sociais e trabalhistas, da política previdenciária, das práticas de formação e requalificação profissional, da ação sindical e da Justiça do Trabalho).

Pois bem, nos termos propostos, a década de 1980 representa, então, a primeira fase da desregulação do trabalho no Brasil, fase esta marcada ainda por um movimento contraditório, em que se tem, de um lado, o início do processo de desestruturação do mercado de trabalho, mas, de outro, a tentativa de se ampliar o raio de abrangência da regulamentação do mercado laboral. Esses dois vetores põem-se em antagonismo explícito ao final da década, de forma que o aprofundamento da desregulação do trabalho nos anos 90 surge como uma solução não definitiva posta em 
marcha pelos governos de orientação liberalizante. Atualmente em pleno andamento, a desregulação do trabalho nos anos 90 se dá no bojo do aprofundamento também da crise econômica mais geral. A especificidade da trajetória de desregulação do trabalho pela década de 1990 é que, ago$\mathrm{ra}$, os dois vetores de sua determinação caminham na mesma direção. Ou seja, em paralelo à desestruturação do mercado de trabalho que se intensifica nos anos 90 , é posto em marcha o processo de desregulamentação do mercado de trabalho, que vem como parte integrante e indissociável de uma ampla agenda de reformas ditas estruturais por seus formuladores, das quais a reforma do Estado é uma das mais importantes (cf. Cardoso Jr. \& Fernandes, 2000b).

Além da reforma do Estado, um outro conjunto de reformas econômicas fundamentais (tais como a liberalização comercial e financeira irrestrita, a privatização abrangente das empresas estatais, uma reforma tributária colada à disciplina fiscal, com redução e focalização dos gastos públicos, dentre outras) veio delimitar o destino recente do país, assegurando a efetivação do que aqui é chamado de a segunda fase da trajetória brasileira de regressão industrial (cf. Cardoso Jr. \& Pochmann, 2000). Esta segunda fase, que teve como palco a década de 1990, foi um período no qual a trajetória descrita pela economia se deu num ambiente macroeconômico distinto daquele que havia caracterizado a crise mais geral dos anos anteriores.

A década de 1990 representou profundas alterações no tocante ao conjunto de expectativas dos agentes, como também desdobramentos concretos diante das novas e incertas perspectivas de reordenamento do modelo de desenvolvimento. Três eventos econômicos particularmente importantes podem ser identificados como responsáveis pela alteração do cenário das decisões domésticas.

Em primeiro lugar, o retorno do Brasil ao circuito financeiro internacional, como receptor de recursos externos, depois de um longo período de estancamento dos fluxos na década de 1980, particularmente a partir da moratória mexicana de 1982, com a crise das dívidas externas dos países em desenvolvimento. Em segundo, o processo de abertura comercial iniciado em 1990, depois de um longo período sob a vigência de um coeficiente relativamente baixo de importações, com política cambial ativa em favor da geração de superávites comerciais. Finalmente, mas não menos importante, a estabilização relativa da moeda nacional, desde o segundo semestre de 1994, depois de um longo período de vigência de um regime de alta inflação e inúmeras tentativas frustradas de estabilização.

Com respeito ao primeiro aspecto, é preciso situar o comportamento global dos fluxos de capitais, desde os últimos anos da década de 1980 até a atualidade, como a mais intensa etapa do movimento geral de internacionalização do capital já verificado mundialmente (cf. Chesnay, 1996). No entanto, ao contrário do movimento de capitais observado nos anos 70, a recente onda de transnacionalização capitalista tem a caracterís- 
${ }^{1}$ Impactos da reestruturação econômica sobre o mundo do trabalho podem ser vistos em Dedecca (1999). tica de revelar de forma radical sua natureza predominantemente financeira, que potencializa os efeitos desagregadores dos processos de reestruturação produtiva em andamento e submete a capacidade de regulação institucional do sistema (cf. Tavares \& Fiori, 1997; Théret \& Braga, 1998).

Assim, a principal conseqüência desse novo formato de captação de recursos externos foi o acirramento da vulnerabilidade internacional, derivada do tipo dominante de inserção dos países ditos emergentes nos novos fluxos de capital. Num contexto em que prevalece uma mobilidade imperfeita de capital, o tipo de inserção externa da economia impõe severas restrições cambiais ao país, quando abordada pela ótica das necessidades de fechamento do balanço de pagamentos. O aumento da vulnerabilidade da economia brasileira em relação a uma crescente dependência de recursos especulativos de curto prazo ratifica a crença em torno da ausência de contribuição destes fluxos de capitais para o incremento do investimento produtivo, comprometendo sobremaneira o potencial de crescimento do país na década (cf. Laplane \& Sarti, 1997; Bielschowsky, 1998a e 1998b).

No que se refere à abertura comercial, e ao significado da globalização sobre os novos processos de reestruturação tecnológica e produtiva, é preciso atentar para o fato de que uma especificidade relevante da dinâmica capitalista atual tem sido a centralização industrial com reconcentração de mercados, em ritmo intenso e abrangência global (cf. Coutinho, 1995) ${ }^{1}$. Este fenômeno, por si só, já seria indicativo do processo desigual de difusão das mudanças tecnológicas em curso, bem como dos efeitos desagregadores sobre as economias menos preparadas, que acabam ficando mais distantes do rol de países desenvolvidos.

Esta fase de intensas transformações tecnológicas tem impactado de forma radical todos os setores econômicos (primário, secundário e terciário), mas com fortes repercussões sobre os setores industrial e de serviços de toda espécie, que se vêem obrigados a definir novos padrões de organização tanto da produção quanto da administração da gestão empresarial. A tendência mais notória é a da oligopolização (via centralização e/ou concentração) à escala global, cujas formas de concorrência se acirram sobremaneira por conta dos fenômenos de interdependência dos mercados mundiais e alianças tecnológicas específicas entre grandes grupos econômicos ou blocos de capitais centralizados (cf. Braga, 1996).

É justamente a emergência e exacerbação deste aspecto, colado à ausência ou precariedade dos mecanismos de regulação do movimento de valorização dos capitais, que autoriza a afirmação de que a dinâmica capitalista atual esteja sendo comandada predominantemente pela lógica de expansão destes grandes grupos econômicos, mas que assumem diferentes formatos dependendo do país de origem ou do arranjo específico que o singulariza. É lícito constatar que quanto maior o grau de exposição de um país à esfera de interesses e atuação destes grandes grupos econômicos, e quanto maior também o coeficiente de participação do país no 
comércio internacional, tanto maiores deverão ser os impactos e repercussões das transformações recentes na órbita produtiva sobre os respectivos espaços de influência. Somado a isto, quanto mais precários os mecanismos de proteção social, notadamente aqueles voltados à regulamentação do mercado de trabalho, mais desagregadores da ordem social e do trabalho deverão ser os efeitos da incorporação das novas tecnologias aplicadas aos processos de produção domésticos.

Assim, a questão dos impactos da abertura comercial e financeira sobre a base produtiva brasileira não pode ser dissociada dos condicionantes gerais que nortearam tanto o processo de abertura da economia nacional aos fluxos internacionais de capitais e mercadorias como o reordenamento das empresas aqui instaladas diante das transformações mundiais em curso. Neste sentido, é válido circunscrever o fenômeno da abertura comercial e financeira a uma das reformas estruturais de cunho liberalizante, como uma das etapas necessárias ao tipo de modernização preconizada pelos representantes e defensores das propostas do Consenso de Washington no país.

Finalmente, o terceiro evento de grande significação econômica passava a ser a convergência das taxas de inflação domésticas com as taxas internacionais, a partir do segundo semestre de 1994. Este fenômeno, no entanto, contou com dois componentes que acompanharam o sucesso do plano Real desde sua implementação, a saber: i) um diferencial positivo de grande magnitude entre as taxas de juros domésticas relativamente às praticadas no exterior, responsável pela entrada de grande parte da massa de recursos externos captados pela economia brasileira nos últimos anos, e ii) a sobrevalorização relativa da moeda nacional, como conseqüência do anterior, e responsável, em última instância, pelo déficit em transações correntes e pela criação de um ambiente interno pouco favorável ao crescimento econômico.

Em suma, no cenário vivido pela economia brasileira nos anos 90, não se pode menosprezar a influência exercida, desde os primeiros anos da década, pelos processos de abertura comercial e financeira ao exterior. Se a abertura comercial foi capaz de segurar a inflação doméstica ao manter a concorrência internacional em condição de permanente contestabilidade dos mercados e preços internos, também demonstrou ser capaz de desarticular o parque industrial aqui constituído, ao impor sérios limites à retomada dos investimentos produtivos em território nacional. E a abertura financeira, se conseguiu inserir o Brasil nos fluxos internacionais de capital, eliminando, ou pelo menos relativizando drasticamente a restrição externa que perdurou sobre o país durante toda a década de 1980, também aprofundou a crise bancária em curso, comprometendo duramente a capacidade de regulação sistêmica por parte das autoridades macroeconômica e monetária.

Por fim, também não se pode ignorar a influência do plano de estabilização (Plano Real) sobre as baixas taxas de crescimento econômico 
durante praticamente toda a segunda metade da década de 1990. Ou seja, se por um lado o plano de estabilização ancorado no Real alcançou relativo sucesso no combate à inflação, por outro, levou a economia brasileira a uma combinação perversa de três armadilhas bem visíveis, sem saída no curto prazo e nas atuais condições.

A primeira armadilha é a da estagnação econômica, onde se constata uma certa incapacidade das forças de mercado em operar o milagre da retomada do crescimento sustentado, em claros sinais de que estabilização sem crescimento do produto não pode se manter indefinidamente. A segunda armadilha é a da crise fiscal e financeira do Estado brasileiro, pela qual se verifica o crescente esgotamento dos mecanismos clássicos de financiamento das contas públicas. Finalmente, a terceira armadilha diz respeito aos próprios sustentáculos da estabilização, cujos anteparos têm se mostrados extremamente vulneráveis e dependentes das condições do mercado internacional. A abertura não seletiva com câmbio flutuante (pós desvalorização em janeiro de 1999) impacta negativamente o crescimento. A estagnação econômica com juros elevados inviabiliza qualquer tentativa de recomposição das condições de financiamento do setor público. Por fim, Estado em situação financeira ponzi acelera a deterioração do cenário político, sintoma inequívoco de aprofundamento da crise latente no país.

Do ponto de vista do mercado de trabalho, por sua vez, as transformações econômicas, engendradas pelo movimento de abertura externa com recessão doméstica no início dos anos 90, agiram no sentido de aprofundar as inserções setoriais ligadas aos serviços prestados às empresas (serviços produtivos), comércio e transportes (serviços distributivos), serviços prestados às famílias (serviços pessoais) e serviços não mercantis (serviços diversos). Ao mesmo tempo, acentuaram-se as inserções ocupacionais dos assalariados sem carteira, trabalhadores autônomos e trabalhadores não remunerados (cf. Cardoso Jr., 1999).

Este panorama geral esconde, portanto, uma situação perversa num duplo sentido. Por um lado, as novas inserções setoriais seriam fruto mais da perda de dinamismo econômico da estrutura produtiva brasileira que de um reordenamento da mesma rumo a um novo padrão de desenvolvimento sustentável. Por outro lado, as novas inserções ocupacionais representariam muito mais estratégias de sobrevivência dos trabalhadores diante do colapso das alternativas de empregabilidade formal com proteção social que uma livre escolha para alcançar ascensão profissional ou pessoal, ainda que muitas destas novas atividades autônomas possam redundar em certo prestígio ou mesmo em rendimentos médios mais elevados nas fases ascendentes dos ciclos (cf. Castro \& Dedecca, 1998).

Ambos os fenômenos - terciarização das ocupações e informa-lização das relações de trabalho - ajudam a explicar também a deterioração da qualidade da maioria dos novos postos de trabalho abertos 
durante a década de 1990, com reflexos perversos sobre a estrutura já bastante concentrada da renda do trabalho pessoal. Assim, ao se confirmar o diagnóstico feito até aqui, seria de se esperar, para os próximos anos, dadas as condições atualmente vigentes no cenário macroeconômico, tanto um aumento das taxas de desemprego aberto, quanto um possível aumento da informalização das relações de trabalho (cf. Cardoso Jr. \& Fernandes, 2000a).

A despeito da desvalorização do Real em janeiro de 1999 e da redução dos juros básicos ao longo de 2000, as informações conjunturais apontam para uma retomada ainda insuficiente do emprego industrial, confirmando, por sua vez, o aparente esgotamento da trajetória de absorção da mão-de-obra pelo setor terciário da economia. Já o aumento da informalização das relações de trabalho parece ser mais provável em um contexto de crescente desregulamentação da legislação trabalhista e do acirramento da competição, no interior da classe trabalhadora, por uma inserção a qualquer custo no mercado de trabalho pouco estruturado do Brasil.

\section{A desregulação pela ótica da desestruturação do mercado de trabalho}

A partir da linha de argumentação esboçada acima, é possível promover uma separação objetiva entre os elementos que diferenciam o ambiente macroeconômico e institucional das décadas de 1980 e 1990 daqueles que constituem pontos comuns ao longo desta trajetória. Entre os elementos diferenciadores, podemos destacar 3 pontos:

1) acesso aos fluxos financeiros internacionais: enquanto os anos 80 foram marcados pelo estancamento radical das correntes de financiamento externas ao Brasil, a década de 1990 representou a volta do país ao circuito financeiro mundial;

2) grau de exposição ou abertura externa: enquanto os anos 80 são lembrados como um período protecionista (de altas tarifas de importação e política cambial voltada à geração de grandes saldos comerciais com o exterior), a década de 1990 tem como uma de suas principais características a abertura comercial externa;

3) inflação: enquanto os anos 80 vivenciaram sucessivos planos mal sucedidos de estabilização, frente a um regime incansável de alta inflação, a década de 1990 presenciou uma estabilidade relativa a partir do segundo semestre de 1994.

Não obstante as especificidades do cenário macroeconômico em cada período, há importantes permanências ao longo de ambas as décadas que, aliás, nem são exclusividade destes anos. Pelo contrário, são heranças ainda não resolvidas da trajetória capitalista no Brasil, dentre as quais podemos destacar 3 grandes continuidades históricas de nossa industrialização, com especial significação para as décadas de 1980 e 1990: 
1) uma instabilidade macroeconômica radical: em ambos os períodos, as principais variáveis do cálculo capitalista (câmbio, juros, preços, salários) oscilaram violentamente no país, a ponto de impedir previsões econômicas seguras a respeito da evolução dos níveis de produto e emprego, com o que se exacerba o risco sistêmico e se aprisionam as decisões empresariais no curto prazo;

2) uma dinâmica de expansão segundo a lógica do stop and go: também em ambos os períodos, inclusive por decorrência da instabilidade macroeconômica radical, instaura-se no país uma dinâmica capitalista truncada, que alterna, num curto espaço de tempo, pequenos ciclos de crescimento e recessão, sem que se vislumbre condições para um desenvolvimento sustentado;

3) uma oferta excedente de mão-de-obra: nestas duas últimas décadas do século XX, em paralelo ao colapso do padrão histórico de desenvolvimento brasileiro, processou-se também a reversão da tendência de estruturação do mercado de trabalho nacional. Este fenômeno se sobrepôs à base já ampla e excedentária de mão-de-obra do país, relativamente à insuficiente e dependente pujança do nosso capitalismo tardio e periférico, exacerbando a assimetria estrutural entre capital e trabalho, de modo a conformar-se num dos mais importantes fatores a explicar a determinação do emprego e das relações de trabalho no período recente.

É justamente neste (e deste) ponto que emerge a primeira tese (ou hipótese) central do estudo, relacionada à tarefa de estabelecer as conexões lógico-históricas entre a crise da economia brasileira dos últimos vinte anos e o processo de desregulação do trabalho no país. Em linhas gerais, esta tese sugere que: em contextos macroeconômicos recessivos, tendo os agentes a percepção de tratar-se de um fenômeno duradouro, $e$ na ausência ou ineficácia de amplas políticas públicas de garantia de renda e proteção social aos trabalhadores e desempregados, a dinâmica de geração das ocupações passa a depender relativamente mais das condições de oferta do que das de demanda por trabalho. Não é à toa, por sinal, que as atividades geradas no comércio e nos serviços pessoais estiveram entre as mais disputadas em período recente, a ponto de se atribuir ao segmento terciário a importante função de colchão absorvedor do excedente estrutural de mão-de-obra do país.

A partir deste aspecto é possível definir e caracterizar cada um dos dois eixos que compõem o quadro de desregulação do trabalho no Brasil em período recente, a saber: a desestruturação e a desregulamentação do mercado de trabalho.

No que se refere à desestruturação do mercado de trabalho brasileiro, já foi dito na introdução que este fenômeno teve início em princípios da década de 1980, no bojo do processo mais geral de desarticulação do modelo de desenvolvimento industrial que havia comandado a economia do país até então. A tendência à desestruturação do mercado de 
trabalho se aprofundaria nos anos 90, justamente no contexto de primazia da política liberalizante que guiou as ações de todos os governos brasileiros do período.

Este amplo processo de desestruturação do mercado de trabalho pode ser empiricamente caracterizado, tendo por base uma definição que ressalta 6 aspectos sintomáticos e estreitamente interligados, a saber:

1) Um crescimento patológico do setor terciário (comércio e serviços) da economia:

A terciarização das ocupações, que já fazia parte do cenário econômico nacional desde princípios dos anos 80 (com quase 50\% de todo o pessoal ocupado localizado no terciário), continuou sua trajetória de absorção de mão-de-obra também pela década de 90 , ainda que a uma taxa média de crescimento decrescente (4,8\% a.a. entre 1981-85, 3,7\% a.a. entre 1986-89, $1,8 \%$ a.a. entre $1990-93$ e 1,2\% a.a. entre 1995-98)2. Assim, em que pese 0 fato da terciarização das ocupações no Brasil ter sido um evento econômico marcante ao longo das duas últimas décadas, é preciso apontar, senão para um aparente esgotamento, ao menos para um arrefecimento desta estratégia de expansão do terciário, com repercussões não desprezíveis sobre as outras quatro dimensões da desestruturação do mercado de trabalho nacional (gráfico 1).

\section{Gráfico 1}

Evolução do pessoal ocupado por setor de atividade - Brasil 1981-1999

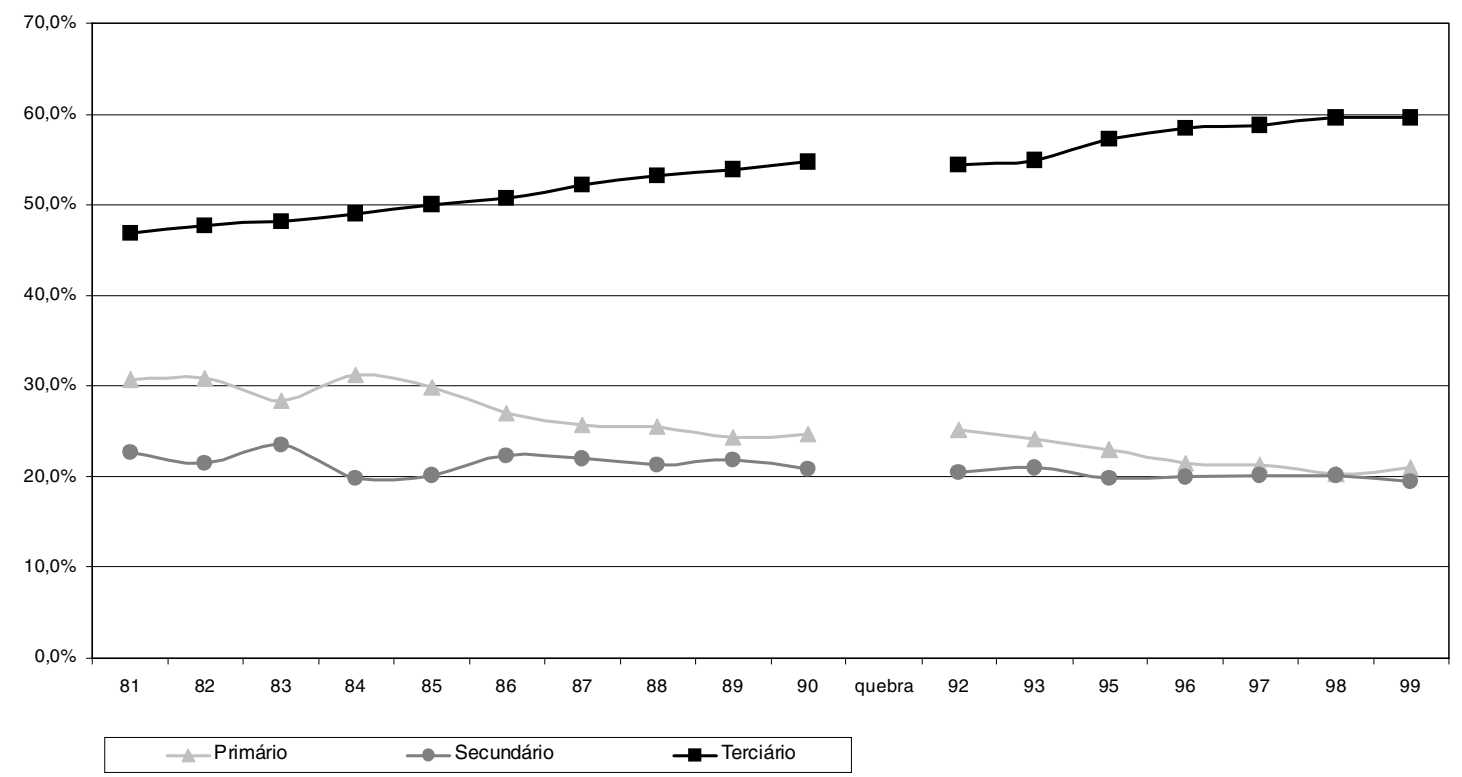


${ }^{3}$ A respeito, cf. Cardoso Jr. \& Fernandes (2000a.)
2)Um crescimento expressivo da informalidade nas relações de trabalho, medida pelo peso crescente dos trabalhadores sem registro, sem remuneração e por conta própria no total da ocupação:

Ainformalização das relações de trabalho no Brasil, embora também já fizesse parte do cenário econômico da década de 1980 (com nunca menos que 50,0\% do pessoal ocupado total localizado em ocupações pertencentes ao núcleo pouco estruturado do mercado de trabalho), apresentou uma tendência de aumento do seu peso relativo no total da ocupação, estacionado em torno dos $60,0 \%$ ao longo dos anos 90 (gráfico 2) ${ }^{3}$. A explosão da informalidade nesta última década, como decorrência da sobreposição entre, de um lado, os movimentos setoriais de reestruturação produtiva e organizacional forçados pela abertura ao exterior e, de outro, as políticas econômicas domésticas de orientação recessiva, geraram um quadro de aprofundamento da heterogeneidade do mercado de trabalho que sinaliza uma situação de deterioração das condições de inserção ocupacional para a maior parte da classe trabalhadora no Brasil. Enquanto nos anos 70 a heterogeneidade era vista como fruto de um crescimento das atividades modernas insuficiente para absorver a disponibilidade existente de força de trabalho, na década de 1990 a heterogeneidade do mercado de trabalho pode ser analisada também como produto da passagem de trabalhadores formais para a situação de informalidade crescente que se acentua pela perda de dinamismo global do sistema econômico (cf. Baltar \& Dedecca, 1997).

\section{Gráfico 2}

Evolução do pessoal ocupado segundo o grau de estruturação do mercado de trabalho - Brasil 1981-1999

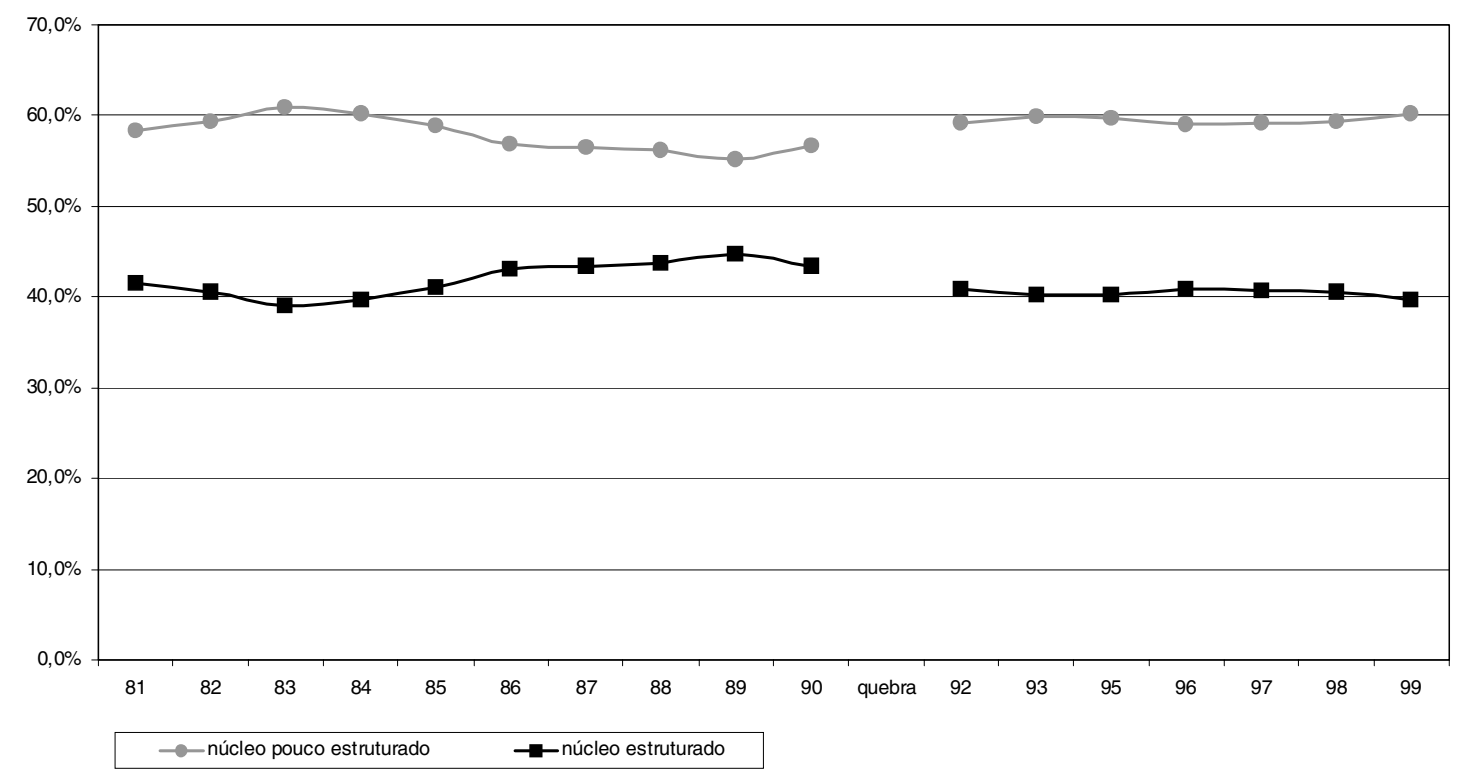

Fonte: Pnad; IBGE. 
3) Um aumento não desprezível dos níveis de desocupação e desemprego:

Os anos 90 também vieram acompanhados de uma mudança de patamar nos níveis médios de desocupação e desemprego da PEA, que praticamente dobra ao final da década em relação aos índices dos anos 80 e começo dos 90, mesmo considerando as estimativas conservadoras da PME-IBGE (gráfico 3). Alguns autores (Amadeo \& Camargo, 1996; Franco, 1999) procuram minimizar este problema, atribuindo o fenômeno contemporâneo do desemprego no Brasil ao conjunto de transformações estruturais em âmbito mundial, resultado, portanto, dos processos de reorganização produtiva e tecnológica e das novas formas de gestão empresarial, com rebatimentos inexoráveis no país, em sua fase atual de crescente abertura e integração junto aos mercados centrais. Mas ainda que se reconheça os impactos oriundos da esfera microeconômica sobre o emprego agregado, não é possível descartar o fato de o ambiente macroeconômico interno estar muito pouco propício ao enfrentamento do desemprego como fenômeno econômico e social de grandes proporções, com conseqüências adversas sobre o conjunto da população e da própria economia (cf. Cacciamali, 1995; Baltar \& Mattoso, 1997).

\section{Gráfico 3}

Desemprego masculino, feminino e total da população de 10 anos e mais - Brasil 1981-1999

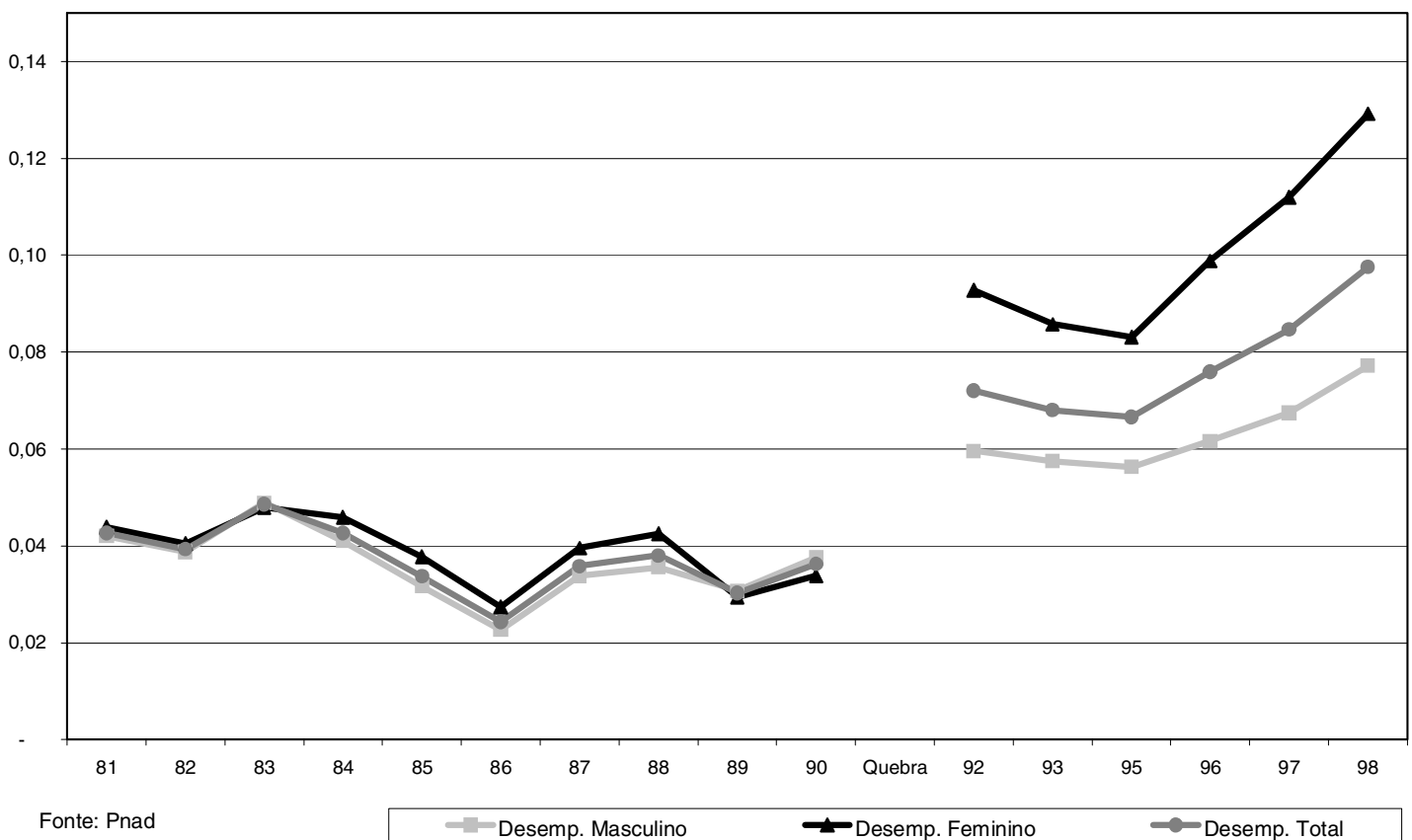


${ }^{4}$ Isto não é, obviamente, o mesmo que dizer que não existam atividades de trabalho precário ou frágeis também no seio da categoria ocupacional de assalariados com carteira, mas sim que neste caso a incidência de inserções desta natureza é bem menor, posto estarem ligadas ao núcleo mais estruturado do mercado de trabalho.

${ }^{5}$ A respeito, cf. Cardoso Jr. (2000).
4) Uma precarização ou piora na qualidade dos postos de tra-

balho:

Intimamente associada à informalização e ao crescimento e diversificação dos tipos de desemprego (friccional, cíclico, sazonal, estrutural, oculto, de inserção, de exclusão), constata-se nos anos 90 uma precarização crescente das relações e condições de trabalho, com aumento da assimetria já existente entre capital e trabalho, especialmente para as categorias ocupacionais tidas como informais, no interior das quais parecem residir as atividades mais precárias, do ponto de vista da qualidade da ocupação - caso claro dos trabalhadores por conta própria-, e de mais frágil inserção profissional, do ponto de vista das relações de trabalho - caso evidente dos sem registro em carteira ${ }^{4}$.

Embora reconhecendo a complexidade conceitual e empírica em definir e mensurar o fenômeno da precarização, é possível constatar, particularmente junto aos assalariados sem carteira, que a ausência de mediação institucional pelo Estado torna mais frágeis e assimétricas as relações capitaltrabalho, favorecendo uma flexibilidade quantitativa (dispensa e contratação de mão-de-obra) muito elevada, que apenas serve para engendrar uma alta rotatividade de trabalhadores nestas ocupações. Como se sabe, níveis muito altos de rotatividade produzem, de um lado, postos de trabalho de baixa qualidade e praticamente nenhum investimento em recursos humanos e, de outro, trabalhadores sem especialização definida, que rodam intensamente por ocupações distintas, sem perspectivas de ascensão profissional nem salarial. De outro lado, a ausência ou precariedade dos mecanismos de proteção social conferidos pelo Estado a seus cidadãos tende a transferir aos âmbitos familiar e individual a responsabilidade pela sobrevivência numa sociedade marcada por uma crescente redundância do trabalho vivo. Este aspecto é particularmente dramático junto aos trabalhadores por conta própria de menores rendas, que tendem a não recolher contribuição previdenciária e tampouco tendem a ter registrados nas administrações públicas seus pequenos negócios.

Em estudos sobre a qualidade dos postos de trabalho, acreditamos que informações sobre a cobertura da seguridade social, tipo e quantidade de benefícios recebidos pelos trabalhadores, jornada de trabalho, número de empregos praticados, permanência no emprego e filiação sindical, entre outros, cobrem um conjunto muito relevante de aspectos ligados à qualidade dos postos de trabalho, livres da dimensão exclusivamente monetária que costuma caracterizar a maioria dos estudos a respeito, e que precisariam ser devidamente considerados (tabela 1$)^{5}$. 
CARDOSO JR., José Celso. Crise e desregulação do trabalho no Brasil. Tempo Social; Rev. Sociol. USP, S. Paulo, 13(2): 31-59, novembro de 2001.

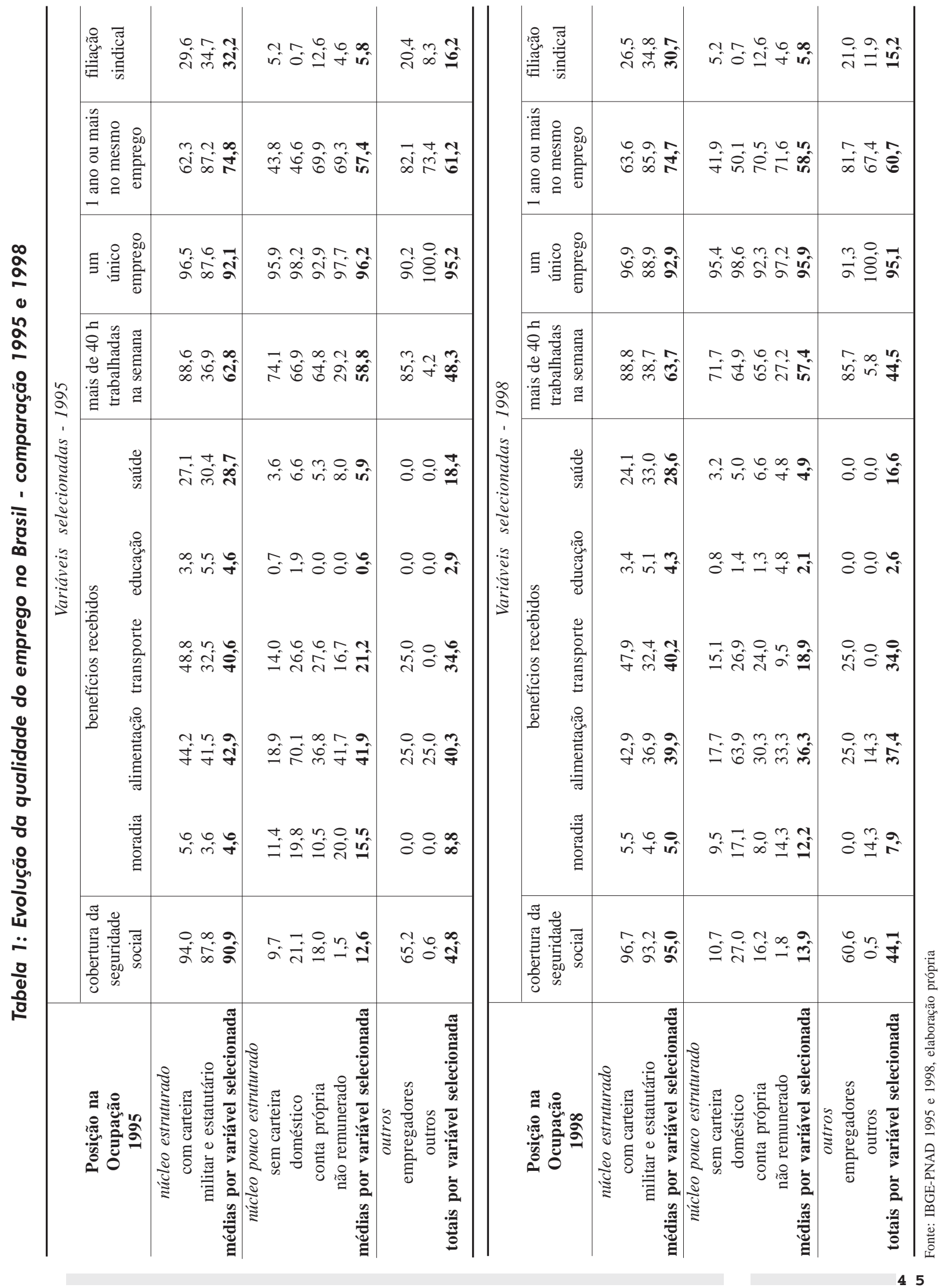


5) Uma estagnação relativa dos rendimentos médios oriundos do trabalho, em particular dos trabalhadores assalariados (com e sem carteira):

Depois de uma década - a de 1980 - marcada por bruscos movimentos de queda e recuperação dos níveis médios dos rendimentos dos trabalhadores ocupados, a década de 1990 foi palco de uma estagnação relativa dos rendimentos médios das principais categorias ocupacionais. Os trabalhadores assalariados, notadamente os vinculados à indústria, tiveram seus rendimentos reais praticamente congelados desde que a abertura comercial acirrou a competição nos mercados domésticos de bens transáveis internacionalmente. Por sua vez, os trabalhadores autônomos, particularmente os ligados ao comércio e serviços, depois de um curto período de euforia no biênio 1995/ 96, viram seus rendimentos reais inverterem a trajetória de crescimento e também refluírem para os níveis observados antes da implantação do Plano Real. Em outras palavras, quando se observa a evolução dos rendimentos reais médios por posição na ocupação desde o início dos anos 80, vê-se claramente que há uma certa estagnação relativa de longo prazo que é ocasionalmente interrompida por efeitos não duradouros de algum plano de estabilização, como no Cruzado em 1986, ou mesmo no Real, entre a segunda metade de 1994 e a primeira de 1997 (gráfico 4).

\section{Gráfico 4}

Evolução do Rendimento Médio Real', por posição na ocupação - Brasil 1981-1999

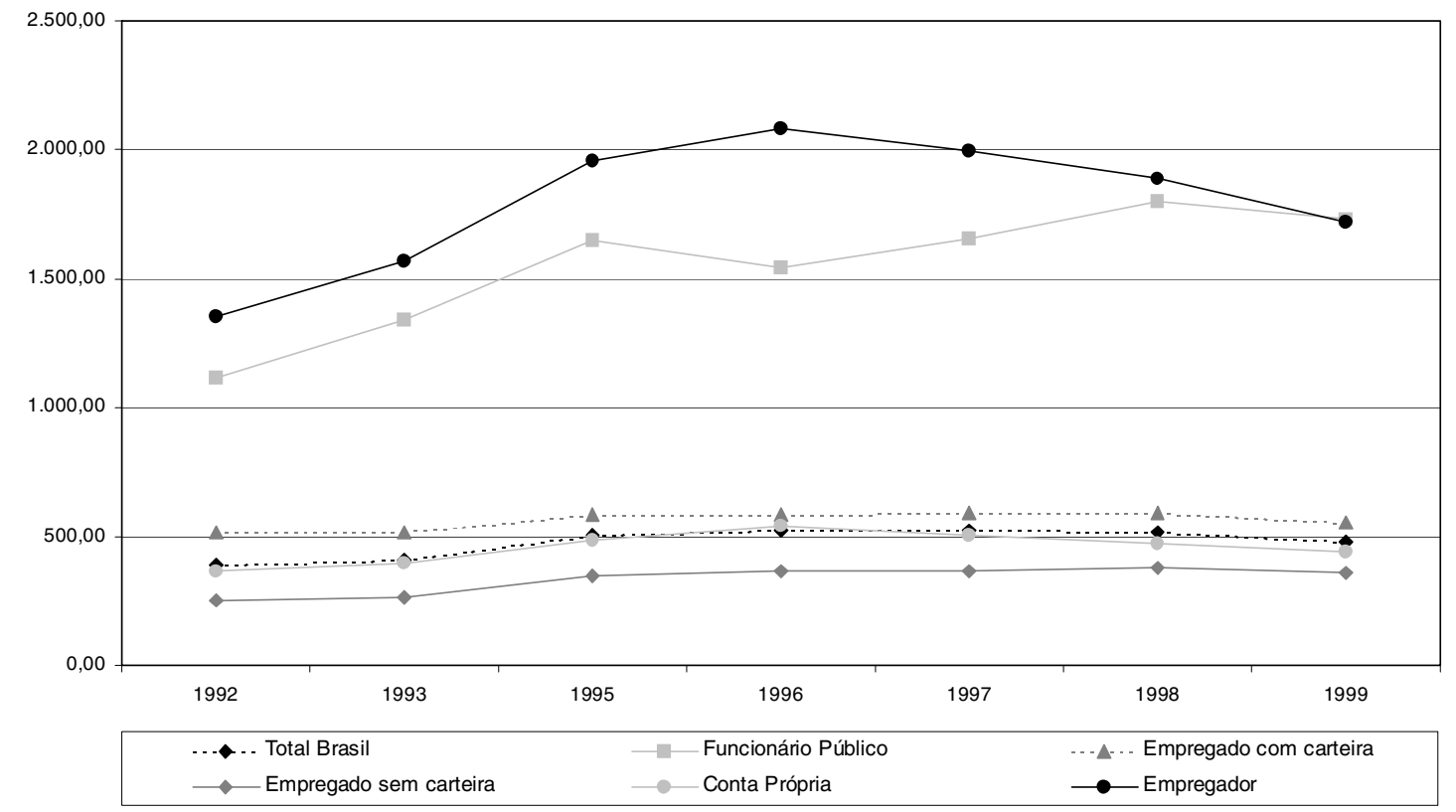

${ }^{*}$ Renda de todos os trabalhos deflacionada pelo INPC/IBGE (base: setembro de 1999). Fonte: Pnad (microdados, 1992/1999). 
6) Uma estagnação relativa da situação distributiva, tanto do ponto de vista da distribuição funcional da renda (repartição entre rendimentos do capital e do trabalho) quanto do ponto de vista da distribuição pessoal dos rendimentos do trabalho:

Do ponto de vista da distribuição funcional da renda, ou mais propriamente, da participação dos salários na renda nacional, esta se apresenta estruturalmente reduzida no Brasil, em comparação com países desenvolvidos, por conta de pelo menos dois fatores que agem na mesma direção ${ }^{6}$.

Em primeiro lugar, a manutenção de um peso elevado de trabalhadores em mercados de trabalho pouco estruturados que, marcados pela ausência de amplos movimentos sindicais organizados e políticas públicas de transferências de renda e proteção social, reproduzem um distanciamento permanente entre ganhos de produtividade e repasses reais aos salários ${ }^{7}$. Em segundo lugar, como reflexo do tipo de crescimento econômico que é imposto pela dinâmica capitalista no Brasil, o ritmo insuficiente de absorção de força de trabalho ativa nos segmentos mais organizados do mercado de trabalho dá origem a uma massa reduzida de remunerações (tabela 2$)^{8}$.

Tabela 2

Evolução da distribuição funcional da renda no Brasil

\begin{tabular}{|c|c|c|c|c|c|c|c|c|}
\hline & \multicolumn{2}{|c|}{ Agropecuária } & \multicolumn{2}{|c|}{ Indústria } & \multicolumn{2}{|c|}{ Serviços } & \multicolumn{2}{|c|}{ Total } \\
\hline & $R n$ / VA & $R n K / R n$ & $R n$ / VA & $R n K / R n$ & $R n$ / VA & $R n K / R n$ & $R n$ / VA & $R n K / R n$ \\
\hline & $\%^{(1)}$ & índice $^{(2)}$ & $\%^{(1)}$ & índice ${ }^{(2)}$ & $\%^{(1)}$ & índice ${ }^{(2)}$ & $\%^{(1)}$ & índice ${ }^{(2)}$ \\
\hline 1985 & 20,2 & - & 35,1 & - & 46,5 & - & 39,4 & - \\
\hline 1990 & 18,2 & 100,0 & 34,9 & 100,0 & 53,7 & 100,0 & 45,0 & 100,0 \\
\hline 1991 & 17,4 & 102,8 & 33,9 & 106,8 & 49,0 & 124,0 & 42,0 & 114,7 \\
\hline 1992 & 18,5 & 95,6 & 30,9 & 126,6 & 46,4 & 145,6 & 39,8 & 130,3 \\
\hline 1993 & 20,5 & 84,3 & 28,4 & 132,6 & 45,2 & 152,9 & 38,4 & 134,3 \\
\hline 1994 & 14,0 & 134,9 & 26,4 & 141,2 & 51,9 & 105,5 & 39,7 & 121,7 \\
\hline 1995 & 13,8 & 141,3 & 26,3 & 139,3 & 53,3 & 96,9 & 40,6 & 115,2 \\
\hline 1996 & 15,1 & 125,4 & 25,9 & 140,7 & 53,3 & 97,6 & 41,1 & 112,0 \\
\hline médias & 17,2 & 3,6 & 30,2 & 5,8 & 49,9 & $-0,3$ & 40,8 & 1,7 \\
\hline \multicolumn{7}{|c|}{$\begin{array}{l}\text { (1) Participação das Remunerações no Valor Adicionado (Rn / VA), segundo a ponderação de cada setor no } \\
\text { total.Remunerações inclui salários e rendimentos dos trabalhadores por conta-própria para os três setores } \\
\text { (2) Índice de Evolução da Relação entre Rendimentos do Capital e do Trabalho (RnK / Rn), com } 1990 \text { = } 100 . \\
\text { Fonte: IBGE; elaboração própria a partir dos dados Matrizes de Insumo-produto. }\end{array}$} & \multicolumn{2}{|c|}{$\begin{array}{l}{ }^{6} \text { Com base em informa- } \\
\text { ções de } 1985 \text {, pode- } \\
\text { se mostrar que “a } \\
\text { participação do salá- } \\
\text { rio no produto inter- } \\
\text { no líquido a custo de } \\
\text { fatores era } 73 \% \text { para } \\
\text { os países industriali- } \\
\text { zados e } 44 \% \text { para os } \\
\text { países da América } \\
\text { Latina" (Kilsztajn, } \\
\text { 1998, p. 61). }\end{array}$} \\
\hline
\end{tabular}


ver integralmente toda a oferta efetiva de mão-de-obra, tem-se necessariamente um perfil altamente concentrado para a distribuição dos rendimentos provenientes do trabalho, que é reforçado pela existência de um nível muito baixo de salários para a maior parte das pessoas pertencentes à base não organizada do mercado de trabalho. Assim, a rigidez à baixa dos índices de desigualdade no Brasil ajuda a reforçar a tese da desestruturação do mercado de trabalho nacional, que consolida e reflete um padrão bastante heterogêneo de ocupações e de remunerações no seio da classe trabalhadora. Ademais, reforça também a inoperância das políticas públicas redistributivas, que assumem cada vez mais um caráter assistencialista e compensatório (gráfico 5).

\section{Gráfico 5}

Evolução temporal da desigualdade de renda - Brasil 1981-1999

7 Ainda usando a mesma referência da nota anterior, pode-se mostrar que "o salário por trabalhador nos países da América Latina correspondia a $13 \%$ do salário dos países industrializados. Ajustado pela PPP para o produto, o salário dos países da América Latina passa para 27\% do salário dos países industrializados. É importante ressaltar que o salário na América Latina não acompanha o nível de produtividade da região em relação aos países industrializados: (...) todos os países industrializados apontam uma relação próxima a 1.0; para a América Latina o nível de salário representa $60 \%$ do nível de produtividade (67\% para o Brasil). O poder de compra do salário na América Latina não acompanha sequer o (baixo) nível de produtividade da região" (Kilsztajn, 1998, p. 63).

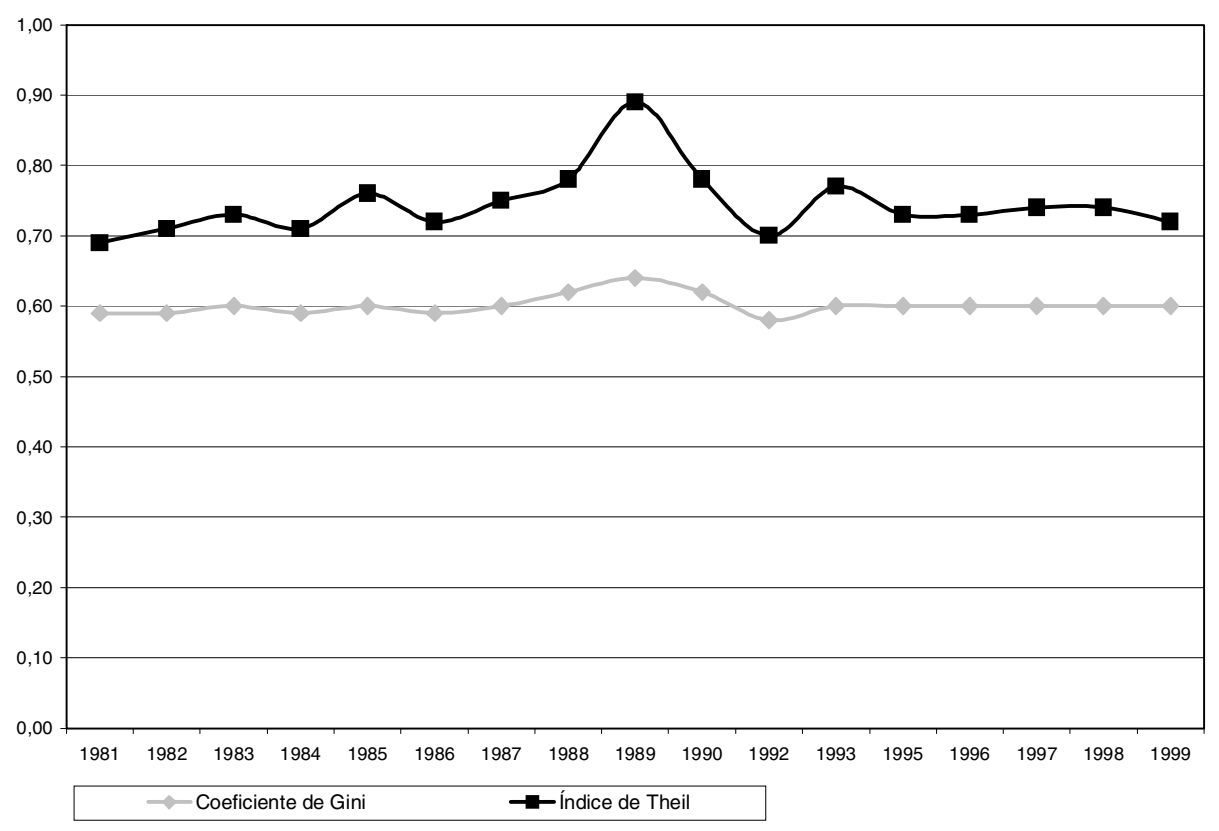

Fonte: Pnad; IBGE.

\section{A desregulação pela ótica da desregulamentação do mercado laboral}

Do ponto de vista da desregulamentação do mercado de trabaIho no Brasil, o segundo dos eixos temáticos relacionado ao objetivo de definir e caracterizar o quadro de desregulação do trabalho em período recente, é possível dizer que tenha passado por dois momentos distintos nestes últimos vinte anos. 
Durante a década de 1980, impulsionado pelos movimentos sociais e sindicais que ganharam força na esteira da redemocratização do país, houve na verdade um processo de ampliação da regulamentação sobre o mercado de trabalho, notadamente em torno da adoção de novos direitos sociais e trabalhistas, cujo ápice se daria com a promulgação de uma nova Constituição Federal em 1988. Esta fase é duplamente importante da perspectiva da regulação do trabalho no país. Em primeiro lugar, porque ocorre num ambiente político de transição de um regime autoritário para um regime democrático, o qual, embora ainda não plenamente constituído e consolidado no país, abria espaço para ações políticas emanadas da sociedade civil, até então alijadas das principais decisões do país. Em segundo lugar, porque ocorre num contexto econômico de crise e desestruturação do mercado laboral, e tem, assim, o sentido de servir de anteparo (ou contracorrente) à dinâmica econômica desagregadora, ainda que talvez isto se tenha dado mais em termos simbólicos que reais.

Já nos anos 90, particularmente a partir de 1994, tem início uma estratégia de desregulamentação do mercado de trabalho nacional, que prima por uma alteração gradual e pontual de itens importantes da legislação trabalhista e social consagrada na CLT e na Constituição de 1988, sendo que apenas de uma perspectiva macro e retrospectiva adquire a dimensão de uma reforma abrangente do sistema de relações de trabalho do país (Cardoso Jr. \& Fernandes, 2000b) ${ }^{9}$.

A idéia-força aqui, a partir da qual emerge a segunda tese (ou hipótese) central do estudo, é a de que a forma pela qual vem sendo conduzida a desregulamentação do mercado de trabalho no país - por meio de medidas provisórias, emendas constitucionais, portarias e decretos, todos objetos de menor resistência política - se constitui numa estratégia deliberada do governo federal, em aliança com determinados grupos sociais de grande expressão (empresários e parte do sindicalismo de resultados), estratégia esta sintonizada às diretrizes mais gerais da reforma do Estado no Brasil.

Este amplo processo de desregulamentação do mercado de trabaIho brasileiro pode ser empiricamente caracterizado por um conjunto de medidas legais que se aglutinam em função de promover importantes mudanças em eixos centrais da organização do trabalho no país. Embora não seja o caso aqui - por falta de espaço - detalhar o significado de cada uma dessas modificações, é possível e desejável elencar as mais relevantes nos últimos anos ${ }^{10}$.

1) Principais mudanças nas condições de uso da força de trabalho:

No que diz respeito às condições de contratação e demissão da força de trabalho, bem como às condições que regulam a jornada oficial de trabalho no país, as primeiras iniciativas de desregulamentação ocorreram já em 1994, no governo Itamar Franco.

Em dezembro de 1994, foi editada a Lei n ${ }^{\circ} 8.949$, conhecida como lei das cooperativas. Ela declara a inexistência de vínculo empregatício entre
${ }^{8}$ Reforçando ambos os aspectos acima mencionados, tem-se no caso brasileiro que tanto a ausência de políticas salariais de orientação estruturante do mercado de trabalho, quanto o poder restrito dos sindicatos na fixação dos salários nominais, constituíram-se em fatores adicionais para manter reduzida a participação dos salários na renda nacional. A respeito, ver Pochmann (1994), Oliveira (1994) e Baltar \& Proni (1995).

${ }^{9}$ Sobre diversos aspectos relacionados à regulamentação do mercado de trabalho no Brasil, ver: Pochmann (1995), Marques (1997) e Cardoso (1999). Sobre os direitos do trabalho, ver: Oliveira (1997) e Antunes (1999).

${ }^{10}$ Para uma visão detalhada deste ponto, ver a versão ampliada do mesmo trabalho, que está para ser publicada ainda em 2001 como Texto para Discussão no IPEA. 
as cooperativas e seus associados, de forma que os trabalhadores assim organizados não são empregados da cooperativa e não têm, portanto, registro em carteira, direitos trabalhistas como férias, $13^{\circ}$ salário, previdência social ou descanso semanal remunerado.

Na mesma linha da flexibilização das condições de uso da força de trabalho vieram a Lei no 9.601 e a MP nº 1.709 , respectivamente, de janeiro e agosto de 1998. A Lei 9.601 trouxe novidades no que diz respeito à contratação de empregados e à jornada de trabalho. Por um lado, ela abriu a possibilidade de contratação de trabalhadores por tempo determinado, desde que em acréscimo aos postos de trabalho já existentes, por um período de até 24 meses, obedecendo aos seguintes limites: 50\% dos trabalhadores, para empresas com até 50 empregados; 35\% dos trabalhadores, para empresas entre 50 e 199 empregados, e $20 \%$ para empresas com mais de 200 empregados. Além disso, durante 18 meses, os contratos por tempo determinado teriam diminuídas em $50 \%$ as alíquotas das contribuições sociais destinadas ao SESI, SENAI, SENAT, SENAS, SESC, SEBRAE, INCRA, salário-educação e financiamento do seguro de acidentes de trabalho. Também se reduziria de $8 \%$ para $2 \%$ a contribuição patronal ao FGTS, além do não pagamento, pelo empregador, da multa de $40 \%$ sobre o saldo do FGTS do trabalhador no momento da rescisão do contrato de trabalho. Por fim, haveria uma redução no preço das horas extraordinárias realizadas sob a vigência de contratos de trabalho por tempo determinado.

Por outro lado, a Lei ${ }^{\circ} 9.601$ veio flexibilizar a jornada de trabalho com a criação do banco de horas, por meio de uma alteração do artigo $\mathrm{n}^{0} 59$ da CLT. O banco de horas permite que o acréscimo de salário seja dispensado se, por força de acordo ou convenção coletiva de trabalho, o excesso de horas de um dia for compensado pela correspondente diminuição em outro dia, de maneira que não exceda, no período máximo de 120 dias, à soma das jornadas semanais de trabalho previstas, nem seja ultrapassado o limite máximo de dez horas diárias.

AMP n 1.709 , por sua vez, além de ampliar o prazo para a compensação das horas extras de 4 meses para um ano, regulamentou o trabalho por tempo parcial, permitindo, assim, uma jornada de até 25 horas semanais. Esse regime de trabalho vale tanto para novas contratações, como para os atuais empregados, desde que eles optem por este novo regime. Neste caso, o salário, assim como os demais direitos trabalhistas, serão determinados conforme a jornada de trabalho semanal. Se a pessoa trabalhar 25 horas por semana, seu salário será $60 \%$ do salário integral e suas férias podem ser reduzidas a 8 dias por ano.

Este conjunto de medidas, além de visar novas contratações amparadas por contratos formais de trabalho (ain la que contratos atípicos: por tempo determinado ou a tempo parcial), destin -se fundamentalmente a rebaixar os custos de contratação e demissão dos tra balhadores do setor privado da economia. A própria introdução do banco de oras, embora seja uma aspiração sindical antiga, aca a por servir, qu se qu exclusivamente, como instrumento de ajuste das ho as trabalhadas is cir unstâncias de curto prazo das 
empresas, na medida em que não vêm acompanhada por um processo de redução da jornada de trabalho e de limitação das horas extras por trabalhador.

Por isso, também junto aos trabalhadores do setor público tem se tomado medidas de desregulamentação da legislação existente, visando, sobretudo, flexibilizar a estabilidade no serviço público para promover, com isso, o ajuste quantitativo no quadro de pessoal. A MP ${ }^{\circ} 1.522$, editada em dezembro de 1997, autoriza a demissão de servidores públicos, conforme critérios estabelecidos em regulamento, se for de interesse da administração federal. Os servidores exonerados devem receber indenização de um mês de remuneração por ano de efetivo exercício no serviço público federal e os cargos vagos em decorrência da exoneração ficam automaticamente extintos.

Em adição, a Lei Complementar n ${ }^{\circ} 96$ definiu os limites para as despesas com pessoal, conforme o artigo $\mathrm{n}^{0} 169$ da Constituição, modificado pela Emenda Constitucional n ${ }^{0} 19$ de junho de 1998. Para tanto, ela disciplina em seu artigo $1^{\circ}$ que as despesas com pessoal não podem ultrapassar 50\% da receita corrente líquida no caso da União, $60 \%$ da receita corrente líquida no caso dos estados e do Distrito Federal, e 60\% da receita corrente líquida municipal. Estes limites foram reafirmados mais tarde na chamada Lei de Responsabilidade Fiscal, aprovada em 2000 por meio da Lei Complementar no 101. A Lei de Responsabilidade Fiscal estabelece, para os entes federados que não estiverem dentro daqueles limites, as condições em que prioritariamente se cortarão gastos, definindo também as penas para os que não convergirem aos limites estipulados em lei. Adicionalmente, obriga aos entes federados a publicação, em órgão oficial de divulgação, do demonstrativo de execução orçamentária do mês e do acumulado dos 12 meses anteriores, em que fique explícito os valores e a forma de cálculo dos mesmos, das receitas correntes líquidas e das despesas totais com pessoal.

As condições para perda de cargo público por excesso de despesa, conforme o estabelecido no artigo 169 da Constituição Federal, foram regulamentadas em junho de 1999, através da Lei n 9.801 , que prevê a exoneração de servidores estáveis "precedida de ato normativo motivado dos chefes de cada um dos poderes da União, dos Estados, dos Municípios e do Distrito Federal”. Esse ato normativo especificará a economia de recursos, o número de servidores a serem exonerados, o órgão e a atividade a serem objeto de redução de pessoal, os critérios para a escolha dos servidores estáveis a serem desligados, além de outras especificações. Ficam também definidas as situações em que os servidores que desenvolvem atividades exclusivas de Estado serão passíveis de serem demitidos, sendo para isso necessário que os servidores dos demais cargos do órgão ou unidade administrativa objeto da redução de pessoal tenham atingido pelo menos 30\% do total desses cargos.

Na esteira da flexibilização das condições de contratação e demissão do emprego público, foram baixadas no começo de 2000 aLei no 9.962 e a MP $n^{\circ} 1.970$ (na verdade, uma reedição da MP nº 1.917). A prir eira estabelece que os admitidos na categoria emprego público serão regidos p las normas da Con- 
solidação das Leis do Trabalho (CLT). A segunda institui o Programa de Desligamento Voluntário (PDV), a jornada de trabalho reduzida com remuneração proporcional e a licença sem remuneração com incentivo pecuniário. Essa MP destina-se aos servidores submetidos ao RJU da União Federal, sendo que as duas últimas novidades representam novas modalidades de flexibilização da legislação trabalhista aplicada ao setor público, em conformidade ao que também vem sendo feito para os trabalhadores do setor privado.

2) Principais mudanças nas condições de remuneração da força de trabalho:

No que diz respeito à remuneração dos trabalhadores, a política dos governos eleitos desde 1989 tem sido no sentido de diminuir cada vez mais a participação do Estado em nome da negociação direta entre empregados e empregadores.

Ainda em 1994 foi editada a MP nº794, que garantiu aos trabalhadores a Participação nos Lucros e Resultados (PLR) da empresa, participação esta desvinculada da remuneração contratual. Além de a PLR precisar ser objeto de negociação coletiva entre os empregados e a empresa, não pode ter periodicidade inferior a 6 meses, de forma a não substituir a remuneração contratual mensal. Com a regulamentação desta MP, o governo desonerou a transferência de recursos das empresas para os empregados a um custo mais baixo, pois o valor acertado na PLR não entra no cálculo das contribuições e direitos trabalhistas.

Em junho de 1995 foi editada a MP nº 1.053, suprimindo os mecanismos tradicionais de reajuste salarial. Os salários e as demais condições de trabalho continuam a ser acordadas através da negociação coletiva, mas fica proibida a fixação de qualquer tipo de cláusula de reajuste ou correção salarial automática. Além da desindexação salarial, essa MP tornou possível, ainda, a adoção imediata do efeito suspensivo dos acordos, o que permite a uma das partes recorrer da decisão de um tribunal de instância inferior.

A desindexação salarial promovida pela $\mathrm{MP} \mathrm{n}^{0} 1.053$ foi reforçada em 1997 com a $\mathrm{MP} \mathrm{n}^{0}$ 1.906, que no mesmo momento que anunciou o salário mínimo de R $\$ 120,00$ também o desvinculou da possibilidade de correção automática por qualquer índice de reposição da inflação, assim como estipulou uma tabela de reajustes para os benefícios previdenciários que utilizava uma referência sem qualquer relação com a reposição salarial ou do custo de vida. Assim, a partir da MP n ${ }^{\circ}$ 1.906, o reajuste do salário mínimo passou a ser definido no mês de maio de cada ano, sob atribuição exclusiva do Poder Executivo. Já em 2000, por meio do projeto de Lei Complementar n 113, a União delegou aos estados a responsabilidade pela fixação do piso salarial, que não poderá ser inferior ao salário mínimo nacional do ano em questão.

3) Principais mudanças nas condições de proteção e assistência à força de trabalho (trabalhadores ocupados e desempregados):

O governo também tem tomado medidas dispondo sobre a proteção social aos trabalhadores, embora nem todas possam ser julgadas benéficas do ponto de vista do bem-estar coletivo. 
Um exemplo disso se deu em setembro de 1995, quando em nome da negociação coletiva, houve um afrouxamento da fiscalização do trabalho por meio da portaria $\mathrm{n}^{\circ} 865$, que instruiu os fiscais do trabalho a apenas comunicarem ao Ministério Público os casos de incompatibilidade entre as condições de trabalho pactuadas em convenção ou acordo coletivo e a legislação pertinente, ao invés de multar a empresa, como mandava a prática anterior.

Já em 1998, o governo abriu a possibilidade para a suspensão temporária do contrato de trabalho para a qualificação do trabalhador, mediante a edição da MP n ${ }^{0}$ 1.726. Segundo essa MP, a suspensão do contrato de trabalho poderá ocorrer por um período de 2 a 5 meses "mediante previsão em acordo ou convenção coletiva de trabalho e aquiescência formal do empregado". Enquanto durar a suspensão, o trabalhador deverá participar de cursos ou programas de qualificação profissional oferecidos pelos empregadores e receberá bolsa de qualificação profissional custeada pelo Fundo de Amparo ao Trabalhador (FAT).

Desde de junho de 1999 , por meio da $\mathrm{MP} \mathrm{n}^{0} 1.779$, a suspensão do contrato de trabalho para qualificação profissional pode ser prorrogada por período indeterminado, mediante convenção ou acordo coletivo e aquiescência formal do empregado, desde que o empregador arque com o ônus correspondente ao valor da bolsa de qualificação profissional. Por este novo procedimento, a desobrigação do empregador frente aos custos da requalificação de seus funcionários fica garantida apenas pelo período de 2 a 5 meses, como contemplado na MP anterior.

Por outro lado, algumas medidas recentes podem ser avaliadas como positivas da ótica dos trabalhadores. É o caso dos programas visando a geração de emprego e renda, bem como das medidas de combate à discriminação por gênero e de extensão dos benefícios do FGTS aos trabalhadores domésticos.

Com relação aos programas de geração de emprego e renda, destaque-se o PROEMPREGO I e II. O primeiro foi criado em 1996 pela Resolução ${ }^{\circ} 103$ do CODEFAT, enquanto o PROEMPREGO II o foi em 1999 pela Resolução ${ }^{\circ} 207$ do CODEFAT. Esses dois programas tinham como objetivo "preservar e expandir oportunidades de trabalho, incrementar a renda do trabalhador, proporcionar a melhoria da qualidade de vida da população, em especial das camadas de baixa renda, e proporcionar a redução dos custos de produção no contexto internacional”.

Outro programa lançado pelo governo com os mesmos objetivos foi o PROTRABALHO. O PROTRABALHO I foi instituído em 1998 pela Resolução no 171 do CODEFAT e o PROTRABALHO II em 1999 pela Resolução $n^{\circ} 210$ do CODEFAT. Esses dois programas estão vinculados à promoção do desenvolvimento regional, com utilização integral de recursos na Região Nordeste do Bras l e Norte do Estado de Minas Gerais.

Outras duas medidas positivas de proteção e assistência aos trabalhadores foram inc uídas na legislação recentemente. De acordo com a Lei no ${ }^{\circ}$.799, editada e m 1999, fica proibido publicar anúncio de emprego fazendo referência a s xo, idade, cor ou situação familiar, bem como recu- 
sar emprego ou promoção com base em alguma dessas características, salvo quando a natureza da atividade seja notoriamente incompatível. Fica também vedado o uso de qualquer dessas características como variáveis determinantes da remuneração, formação profissional ou para fins de ascensão profissional.

Já em 2000 foram acrescentados dispositivos à Lei $n^{0} 5.859$, por meio da $\mathrm{MP}^{\circ}{ }^{1}$ 1.986, para possibilitar o acesso dos empregados domésticos ao FGTS. Desta forma, o empregado doméstico que for dispensado sem justa causa terá direito ao benefício do seguro desemprego, no valor de um salário mínimo, por um período máximo de três meses, de forma contínua ou alternada. O benefício será concedido ao empregado inscrito no FGTS que tiver trabalhado como doméstico por um período mínimo de 15 meses nos últimos 24 meses contados da dispensa sem justa causa e será pago com recursos do FAT.

4) Principais mudanças relativas à reforma sindical e da Justiça do Trabalho:

A política de desregulamentação e flexibilização do mercado de trabalho brasileiro tem se disseminado também no âmbito da organização sindical e da Justiça do Trabalho.

Em 1996, o Projeto de Lei $n^{0} 1.802$ acrescentou dispositivos à lei de greve, dentre as quais se destacam os que atribuem aos sindicatos toda a responsabilidade pelas greves, estabelecendo multas de 500 a 1.000 salários mínimos por dia ao sindicato que desobedecer a decisão judicial de abusividade de greve. $\mathrm{O}$ valor da multa é determinado de acordo com a situação econômica do sindicato e esta pode ser revogada se não houver outra greve abusiva dentro de cinco anos. Nesse mesmo sentido, foi editado também em 1996, o Decreto $\mathrm{n}^{\circ} 2.066$, no qual o governo limita o número de licenças concedidas a servidores públicos para o cumprimento de mandato em cargo de direção ou representação em confederações, federações e associações. Enquanto a primeira medida estabelece o cerceamento do direito de greve, esta outra incentiva a desmobilização sindical dos servidores públicos.

O Projeto de Lei n 3.003 de 1997, por sua vez, prevê a redução do número de contribuições sindicais, com o fim da taxa assistencial, mas manutenção da mensalidade dos associados, criando-se a chamada contribuição negocial. Essa contribuição seria descontada na folha salarial, em até três vezes, de acordo com o valor estabelecido em assembléia geral. A contribuição não deixaria de ter caráter compulsório, mas os trabalhadores poderiam optar pelo seu não recolhimento, desde que aprovado por uma assembléia de pelo menos $10 \%$ dos trabalhadores, sindicalizados ou não. Os não sindicalizados seriam obrigados a contribuir da mesma forma que os associados. $\mathrm{O}$ sindicato, por sua vez, zelaria pelos interesses de toda a categoria, incluindo sindicalizados e não sindicalizados.

Através da Proposta de Emenda Constitucional no 623 da 1998, pretende-se realizpr uma mudança significativa na organização dos sir dicatos brasileiros, dandd nova redação aos artigos $8^{\circ}, 111^{\circ}$ e $114^{\circ}$. A princip ll mudança 
extingue a representação sindical única (unicidade sindical) em uma área territorial, abrindo a possibilidade de que mais de um sindicato concorra pela representação de uma categoria ou grupo de trabalhadores num mesmo município. Pela nova proposta, os sindicatos deixam de ser representantes de uma categoria por sua natureza, e passam a representar somente os interesses de seus filiados. Está prevista também uma alteração na forma legal de institucionalização dos sindicatos. A proposta prevê o fim da necessidade de registro do sindicato em órgão competente do poder público (representação sindical), exigindo apenas o registro como pessoa jurídica na forma da lei civil.

A PEC 623/98 prevê, ainda, a criação do Conselho da Justiça do Trabalho, a funcionar junto ao Tribunal Superior do Trabalho (TST), e cuja missão é exercer a supervisão administrativa e orçamentária da Justiça do Trabalho, em primeiro e segundo graus. A composição do conselho e sua forma de atuação deverão ser regulamentadas posteriormente.

Além disso, a mesma PEC propõe uma delimitação das competências da Justiça do Trabalho, restringindo aos dissídios de natureza jurídica seu campo de atuação. Os dissídios de natureza econômica, por exemplo, passam a ficar fora da alçada da Justiça do Trabalho. A PEC prevê também que os conflitos de direito sindical sejam incorporados ao campo de atuação da Justiça do Trabalho.

No início de 2000, foram introduzidas duas modificações importantes ao funcionamento da Justiça do Trabalho, instituídas pelas Leis $\mathrm{n}^{\circ} 9.957$ e n ${ }^{\circ} 9.958$.

A Lei no 9.957 acrescenta à CLT uma seção que prevê a implantação do procedimento sumaríssimo para dissídios individuais, cujo valor não ultrapasse 40 salários mínimos. O objetivo é tornar rápida e ágil a solução para demandas processuais trabalhistas individuais de baixo valor. O processo sumaríssimo reduz procedimentos burocráticos, prazos legais e define que as demandas serão instruídas e julgadas em audiência única, visando sempre a conciliação e o acordo entre as partes em litígio. As demandas provenientes da administração pública foram excluídas da possibilidade de serem submetidas a este procedimento de resolução de conflitos.

Também com o intuito de reduzir o número de processos na justiça trabalhista, foi editada a Lei ${ }^{\circ} 9.958$, que autoriza as empresas e os sindicatos a criarem Comissões de Conciliação Prévia com o objetivo de tentar conciliar os conflitos individuais de trabalho, evitando que conflitos passíveis de solução extrajudicial cheguem à Justiça do Trabalho. Toda comissão instituída deve ter composição obrigatoriamente paritária, com representantes dos empregados e dos empregadores, totalizando no mínimo 2 e no máximo 10 membros. A comissão pode ser constituída no âmbito de uma única empresa e seus empregados, ou por um grupo de empresas e ter caráter intersindical.

Instituída a comissão, todas as demandas de natureza trabalhistas serão a ela submetidas. Em posse da demanda, a comissão deve convocar as partes num prazo máximo de 10 dias para a realização de sessão de concilia- 
ção. Caso a sessão consiga atingir seus objetivos, será emitido um título executivo extrajudicial com eficácia liberatória passível de execução pelo juiz que arbitraria a demanda caso esta se tornasse um processo. Caso o resultado da sessão não convirja para um acordo entre as partes, a comissão deverá emitir uma declaração de tentativa de conciliação, que deve ser anexada à petição inicial de ação junto à Justiça do Trabalho.

Em suma, as medidas tomadas no âmbito da reforma sindical e da Justiça do Trabalho visam, sobretudo, estimular a livre negociação entre patrões e empregados, facilitando a organização sindical e reduzindo os custos processuais e de intervenção da Justiça do Trabalho na resolução dos conflitos de natureza trabalhista.

\section{4. À guisa de conclusão: condições políticas para superação da crise}

Diante do quadro sucintamente esboçado acima, é imperativo avançar na sugestão de alguns pontos de reflexão para a tentativa de se construir uma agenda positiva de mudanças, como condição para a superação do binômio crise econômica e desregulação do trabalho no Brasil.

Para tanto, é imprescindível salientar que é preciso abordar e atacar a relação entre crise econômica e desregulação do trabalho de uma perspectiva ampla, e que soluções pontuais para enfrentar cada uma das partes componentes do grande problema que se tem sob foco têm dado origem, atualmente no país, a uma estratégia insuficiente e ineficaz diante da natureza e gravidade da questão. Em outras palavras, é preciso ter claro que somente uma conjunção de fatores e políticas públicas virtuosas e duradouras no tempo pode desarmar a conexão crise e desregulação do trabalho no país, dentre as quais 3 são particularmente importantes e urgentes:

1) recuperação do crescimento econômico em bases mais sólidas e níveis mais elevados que os atuais;

2) construção de mínimos civilizatórios para a regulação (estruturação e regulamentação) do mundo do trabalho;

3) promoção politicamente deliberada da distribuição funcional e pessoal da renda.

Em suma, somente com uma perspectiva positiva de integração social, portanto, não excludente como a que tem comandado as esferas de dominação política e econômica vigentes no país, é que os anos vindouros do novo milênio podem vir a representar um período histórico de grande importância para o Brasil, rumo à superação dos impasses nos quais está atualmente inserido. Atravessamos um momento crítico desta trajetória, cuja resolução definirá o tipo de país que teremos no futuro. 
CARDOSO JR., José Celso. Crisis and deregulation of labor in Brazil. Tempo Social; Rev. Sociol. USP, S. Paulo, 13(2): 31-59, November 2001.

\begin{abstract}
This study discusses, from a historical-structural perspective, the recent trajectory (1980-2000) of the transformations of Brazilian economy, especially with regard to the implications for the labor market. Putting it briefly, there are three aspects of interest in the text. The first is related to the task of establishing logical-historical connections between the crisis in the Brazilian economy of the last twenty years (1980-2000) and the process of labor deregulation in the country. The second refers to defining and characterizing each of the two axes that, from our point of view, make up the scenario of labor deregulation in Brazil in recent years, as follows: destructuralization and deregulation of the labor market. Finally, the third aspect involves suggestions of some points to reflect on in order to build a positive agenda of changes, as a condition to overcome the binomial economic crisis and labor deregulation in Brazil.
\end{abstract}

TEY WORDS: economic crisis, deregulation, destructuralization, deregulamentation, labor market, Brazil.

\section{REFERÊNCIAS BIBLIOGRÁFICAS}

Amadeo, Edward \& CAMARgo, José Márcio. (1996) Instituições e o mercado de trabalho no Brasil. In: CAmargo, José Márcio (org.). Flexibilidade do mercado de trabalho no Brasil. Rio de Janeiro, FGV.

AntunEs, Ricardo. (1999) Os sentidos do trabalho: ensaio sobre a afirmação e a negação do trabalho. São Paulo, Boitempo.

BAER, Mônica. (1993) O rumo perdido: a crise fiscal e financeira do Estado brasileiro. Rio de Janeiro, Paz e Terra.

Baltar, Paulo \& Proni, Marcelo. (1995) Flexibilidade do trabalho, emprego e estrutura salarial no Brasil. Cadernos do Cesit, Campinas, (15).

\& Dedecca, Claudio S. (1997) Mercado de trabalho no Brasil: o aumento da informalidade nos anos 90. Campinas, IE-Unicamp, mimeo.

\& Mattoso, Jorge E. (1997) Transformações estruturais e emprego nos anos 90. Ensaios FEE, Porto Alegre, 18(1), dezembro.

BIELSCHOWsky, Ricardo. (1998a) Os investimentos fixos na economia brasileira nos anos 90: apresentação e discussão dos números relevantes. Brasília, CEPAL, mimeo.

. (1998b) Investimentos na indústria brasileira depois da abertura e do real: o mini-ciclo de modernizações 1995-97. Brasília, CEPAL, mimeo.

BRAGA, José C. (1996) Economia política da dinâmica capitalista. Texto de Discussão, Campinas, (51), IE-Unicamp. 
Cacciamali, Maria Cristina. (1995) Mercado de trabalho brasileiro nos anos 90: menos empregos, mais política pública. São Paulo, IPE-USP, mimeo.

Cardoso, Adalberto M. (1999) Sindicatos, trabalhadores e a coqueluche neoliberal: a era Vargas acabou? Rio de Janeiro, FGV.

CARdoso JR., José C. (1999) Anatomia da distribuição de renda no Brasil: estrutura e evolução nos anos 90. Campinas, Dissertação (Mestrado). Instituto de Economia da Unicamp.

(2000) Desestruturação do mercado de trabalho brasileiro e limites do seu Sistema Público de Emprego. Texto para Discussão, Brasília, (751), IPEA.

\& Pochmann, Marcio. (2000) Raízes da concentração de renda no Brasil: 1930 a 2000. Brasília/Campinas, IPEA/CESIT, mimeo.

\& Fernandes, S. (2000a) Terciarização das ocupações e informalização das relações de trabalho no Brasil: PNAD 1981 a 1998. Brasília, IPEA, mimeo.

$\&$ . (2000b) Reforma do Estado e desregulamentação do trabalho no Brasil nos anos 90. Anais do V Congresso Internacional del CLAD, sobre la Reforma del Estado y de la Administración Pública, Santo Domingo, República Dominicana, outubro.

CARneIRo, Ricardo. (1992) Crise, estagnação e hiperinflação: a economia brasileira nos anos 80. Campinas. Tese (Doutorado). Instituto de Economia da Unicamp.

Castro, Nadya A. \& Dedecca, Claudio S. (1998) A ocupação na América Latina: tempos mais duros. São Paulo/Rio de Janeiro, ALAST.

Chesnay, François. (1996) A mundialização do capital. São Paulo, Xamã.

CoutinHo, Luciano. (1995) Notas sobre a natureza da globalização. Economia e Sociedade, Campinas, (4), junho.

CRuz, Paulo R. Davidoff. (1984) Dívida externa e política econômica: a experiência brasileira nos anos setenta. São Paulo, Brasiliense.

DedeCCA, Claudio S. (1999) Racionalização econômica e trabalho no capitalismo avançado. Campinas, IE-Unicamp, mimeo.

FIORI, José L. (1995) Em busca do dissenso perdido: ensaios críticos sobre a festejada crise do Estado. Rio de Janeiro, Insight Editorial.

Franco, Gustavo. (1999) O desafio brasileiro: ensaios sobre desenvolvimento, globalização e moeda. São Paulo, Ed. 34.

KiLszTAjn, Samuel. (1998) Produto, capital e taxa de lucro: países industrializados e América Latina. R.E.P., Rio de Janeiro, 18(3).

Laplane, Mariano \& SarTi, Fernando. (1997) O investimento direto estrangeiro e a retomada do crescimento sustentado nos anos 90 . Cam- 
pinas, IE-Unicamp, mimeo.

MArques, Rosa M. (1997) Proteção social e o mundo do trabalho. São Paulo, Bienal.

Medeiros, Carlos \& Salm, Claudio. (1994) O mercado de trabalho em debate. São Paulo, Novos Estudos, CEBRAP, (39).

Mattoso, Jorge E. \& Pochmann, Marcio. (1998) Mudanças estruturais e o trabalho no Brasil dos anos 90. Economia e Sociedade, Campinas, (10), junho.

Oliveira, Carlos A. B. (1994) Contrato coletivo e relações de trabalho no Brasil. In:__ _ Mattoso, Jorge E. et alii (orgs.). O mundo do trabalho: crise e mudança no final do século. São Paulo, Scritta.

Oliveira, Francisco de. (1997) Os direitos do anti-valor. Rio de Janeiro, Vozes.

Pochmann, Marcio. (1994) Trinta anos de políticas salariais no Brasil. In: Oliveira, Carlos A. B.; Mattoso, Jorge E. et alii (orgs.). O mundo do trabalho: crise e mudança no final do século. São Paulo, Scritta.

. (1995) Políticas do trabalho e de garantia de renda no capitalismo em mudança: um estudo sobre as experiências da França, da Inglaterra, da Itália e do Brasil desde o segundo pós-guerra aos dias de hoje. São Paulo, LTr.

Tavares, Maria da C. \& Fiori, José L. (1993) Desajuste global e modernização conservadora. Rio de Janeiro, Paz e Terra.

\&___ (orgs.). (1997) Poder e dinheiro: uma economia política da globalização. Petropólis, Vozes.

Théret, Bruno \& Braga, José C. (orgs.). (1998) Regulação econômica e globalização. Campinas, IE-Unicamp, mimeo. 